(2)

\title{
Quality Test of Student Worksheets Based on Contextual Teaching And Learning for Class XI High School Physics
}

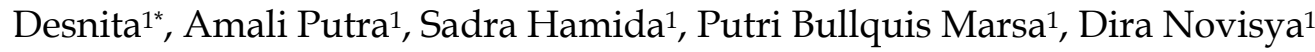 \\ ${ }^{1}$ Faculty of Mathematics and Natural Sciences, Padang State University, Padang, Indonesia.
}

DOI: $10.29303 /$ jppipa.v7i1.600

\section{Article Info}

Received: November $11^{\text {th }}, 2020$

Revised: January 15 1 th 2021

Accepted: January 24th, 2021

\begin{abstract}
This study aims to produce teaching materials in the form of CTL-based worksheets for class XI at Senior High School. The method used in this research is the method of development. The initial stage is an analysis of the teaching materials used by teachers at school. Before being tested on class XI students, the worksheets were validated by experts as well as physics teachers and students at Senior High School 1 Gunung Tuleh. After being validated, improvements were made according to the suggestions given. The average results of the validation of learning experts, physicists, and linguists were $0.77,0.90$, and 0.81 from all aspects. The practical value of teachers and students is 79.68 and 87.43 with the valid category. After testing the validity and practicality of the physics learning videos, the results of the effectiveness test of the learning videos were obtained to measure students' critical and creative thinking skills. The average $\mathrm{N}$-gain values are 0.22 and 0.26 . With the overall results obtained, it can be concluded that the contextual-based worksheets that have been developed are suitable for use in learning activities.
\end{abstract}

Keywords: Curriculum 2013; 21st Century Learning; CTL; Teaching Materials; Worksheets.

Citation: Desnita, D., Putra, A., Hamida, S., Marsa, P., \& Novisya, D. (2021). Quality Test of Student Worksheets Based on Contextual Teaching And Learning for Class XI High School Physics. Jurnal Penelitian Pendidikan IPA, 7(1), 92-101. doi:https://doi.org/10.29303/jppipa.v7i1.600

\section{Introduction}

The 2013 curriculum is a curriculum that is applicable and implemented in schools today. The 2013 curriculum is a development and refinement of the previous curriculum to respond to various internal and external challenges. This is in accordance with the explanation of the Minister of Education and Culture of the Republic of Indonesia (Mendikbud RI) regarding the development of the 2013 Curriculum, teachers are expected to be information literate, media literate, learning resources and ICT literate. The 2013 curriculum aims to prepare Indonesians who can be obedient, productive, creative, innovative, and effective individuals (Astra, et al., 2015). The 2013 curriculum has a changing impact on the learning process of the 21st century. 21st Century learning is learning that requires students to have the skills or competencies that need to be possessed to face the development of this globalization era. The 21st century is an era where the most prominent factors are thoughts and knowledge of both individuals and organizations (Cintamulya, 2012). In this 21st century, education has an important role in shaping the character and morals of the Indonesian nation (Putri, et al, 2018). Various challenges that must be faced in this 21st century include globalization, technology, migration, international competition, market changes, environmental challenges, and international politics (Mahanal, 2014). This can be seen from the implementation of the 2013 curriculum which is in line with the development of the 21st century (Ramdani, A, et al, 2019). In the 2013 curriculum, learning activities use a scientific approach, which is recommended to use the inquiry learning model, 
discovery learning, problem-based learning, and project-based learning as written in Law No. 22 of 2016 concerning process standards. The contextual approach guides students to be actively involved in learning activities to demonstrate their abilities (Hasanah, et al., 2020).

The contextual approach is also known as the CTL approach, which helps students to connect the material being studied with facts that exist in everyday life (Khaerunnisa, et al., 2020). Contextual is a learning process that helps teachers to convey learning material with real situations and encourages students to organize scientific approaches and apply them in everyday life. Contextual is a learning concept that helps teachers link the material they learn to students' real-world situations and encourages students to make connections between their knowledge and its application in everyday life by involving seven components of effective learning, namely: constructivism, finding, asking, the learning community, modeling, reflection, and actual assessment (Smith, 2010). This is in accordance with the opinion of Kaymakci, (2012) that contextual learning is a learning concept that encourages connecting the material being taught and students' real situations.

Contextual learning allows students to connect the content of teaching materials with the real-life context of students to achieve learning goals (Susialita, 2016). Where students learn through experience not by memorizing. Knowledge is not a collection of facts and concepts that are immediately accepted but something that must be constructed by students (Jauhari, 2011). Contextual learning has been widely used in physics subjects (Fadhilah, et al., 2016). Because learning physics will be more meaningful if students learn from their experiences and not only know. In addition, with the times, the way students learn will change according to the development of the world of education (Pineda, 2020). The contextual learning approach does not use the teaching and learning process but uses learning terminology (Asrizal, et al., 2018). To support the achievement of learning objectives and be able to guide children to learn according to a scientifically based approach or model or to apply scientific steps, teaching materials are needed.

Teaching materials are learning tools used by teachers that contain material and are systematically arranged to encourage students to learn (Ifdhal, 2013). The use of teaching materials has a very large role in learning activities. One of the teaching materials is used to help teachers deliver learning material and create student-centered learning. In addition, teaching materials replace the role of the teacher in learning activities so that it helps students to be actively involved and allows students to learn on their own according to their abilities and interests (Al-Adiyah, et al, 2018).
Teaching materials that are good for use in learning activities are teaching materials that are easy to understand and can increase the desire to learn. Designing teaching materials is one of the steps to deliver learning material so that students can easily accept the material presented (Khasanah, B, U, et al, 2019). In teaching materials, there is information to achieve certain goals (Budiarso, 2016). Therefore, we need a teaching material that is more interesting and can make it easier for students to learn and absorb all the information contained in teaching materials so as to create effective and innovative learning. Innovative learning can change the educational paradigm from teacher-centered learning to student-centered (Bustami \& Corebima, 2017; Karim et al., 2018). Teaching materials are usually compiled by teachers or instructors from several learning sources (Desnita, et al., 2014). One of the teaching materials that can help students to be actively involved in learning activities is worksheets (Puspita, et al., 2017).

Worksheets are one of the teaching materials that can assist teachers in delivering learning materials. Student Worksheets are a learning resource that can be developed by teachers as facilitators in learning activities (Nilawati, et al., 2017). Student Worksheets are printed teaching materials used by teachers to help students acquire knowledge, skills, and values, by involving students in effective learning to achieve learning goals (Kaymakci, 2012). In addition, worksheets are also printed teaching materials in the form of sheets of paper containing material, summaries, and instructions for carrying out tasks that must be done by students, which refer to the basic competencies achieved (Sugiyono, 2017). So, worksheets are printed teaching material in the form of sheets containing a summary of the material and assignments that will be done by students according to the basic competencies to be achieved. Worksheets in accordance with student needs are oriented to basic competencies, train students to be active and independent, make it easier for students to understand the material provided, are concise and rich in tasks to practice and are suitable for use (Wildan, et al., 2016).

The structure of the worksheets in general consists of the title of the material, study instructions, competencies to be achieved, supporting information, tasks, and work steps (Depdiknas, 2006). The purpose of using worksheets is to increase student activity in learning activities. The worksheet is a learning resource that can be developed by teachers as facilitators in learning activities (Nilawati, et al., 2017). Worksheet makes learning more meaningful (Isnaningsih, 2013). Previously, the research team had developed contextualbased physics learning videos. However, in reality, videos have not been able to produce maximum impact 
if they are not equipped with worksheets. So this research aims to develop contextual-based worksheets that can maximize the function of contextual-based physics learning videos in meeting learning needs and facilitating the achievement of high school physics competencies in class XI.

To obtain quality worksheets, validation is first carried out. A learning device developed is said to be of high quality, if it meets the valid, practical, and effective criteria (Nieven, 2010). Learning devices are said to be valid if there is a consistent relationship between each component of the learning device developed with the characteristics of the applied learning model (Asikin \& Cahyono, 2008), it is said to be practical if the device is easy and can be implemented, and it is said to be effective if the learning objectives can be achieved through the use of developed learning tools (Nieveen, 1999). Thus, the validity, practicality, and effectiveness of learning tools are very supportive in creating conducive learning and achieving the expected results.

\section{Method}

The population is the subject or object determined by the researcher and has certain qualities and characteristics to conclude and study (Sugiyono, 2017). The subjects of this study were 5 experts as validators, namely physics lecturers at Padang State University. Meanwhile, the object/research sample is the validity test, practicality, and effectiveness of contextual-based worksheets. This type of research is development research (Educational Research and Development), namely a research method used to produce educational products and to test the effectiveness of these products (Sugiyono, 2017). The model used in this development is the ADDIE development model. According to Tegeh, et al., (2014) that the ADDIE model is developed systematically and rests on the theoretical foundation of learning design. This model is structured programmatically with systematic activities to solve learning problems related to learning resources that are in accordance with the needs and characteristics of students. The ADDIE model consists of five stages, namely: 1) analysis, 2) design, 3) development, 4) implementation and 5) evaluation (Riduwan, 2009).

To test the quality of the physics learning worksheets, validity, practicality, and effectiveness instruments are needed. The worksheets validation was carried out by 5 validator lecturers who were experts in their fields. 3 learning expert lecturers, 1 physics expert lecturer, and 1 linguist lecturer. To see the practicality of using instructional videos in the learning process, practical instruments are needed. The practicality instrument is divided into 2 sets, namely the teacher practicality instrument and the student practicality instrument. Both of these instruments were assessed by teachers and students. While this effectiveness instrument is needed to see to what extent the effectiveness of learning worksheets in the learning process using instruments, namely instruments of critical thinking skills and creative thinking skills.

The validity of the learning worksheets that have been made can be seen from the validity sheets filled out by learning experts and physicists. Analysis of the validity of the product was carried out using descriptive statistics depicted in graphs. Weighting was carried out based on the Likert scale. According to Sugiyono (2017), "the Likert scale is used to measure the attitudes, opinions, and perceptions of a person or group of people about social phenomena". With a Likert scale, the variables to be measured are translated into variable indicators. Then these indicators are used as a starting point for arranging instrument items which can be statements or questions. The answer to each instrument item using the Likert scale has a gradation from very positive to very negative which is expressed as follows: score (5) for very good answers, score (4) for good answers, score (3) for sufficient answers, score (2) for poor answers, and a score of (1) for very poor answers.

To find out the value obtained by dividing the score obtained by students by the maximum score, and multiplying by 100 . Systematically, the value of each indicator is determined from the equation:

$$
\text { Score }=\frac{\text { score obtained }}{\text { total score }} \times 100 \%
$$

The validity category is based on Aiken's V coefficient. The validity value is given by using the Aiken's $\mathrm{V}$ formula, namely:

Where:

$$
V=\frac{\sum s}{[n(c-1)]}
$$

$\mathrm{s}=\mathrm{r}-\mathrm{lo}$

Information:

lo = the lowest number of validity assessments

$\mathrm{c}=$ the highest number of validity assessments

$\mathrm{r}=$ the number given by the validator

$\mathrm{n} \quad=$ number of validators

The validity category of the products developed according to Azwar (2015) can be seen in Table 1.

Table 1. Category of Validity

\begin{tabular}{ll}
\hline Score & Criteria \\
\hline$\geq 0.6$ & Valid \\
$<0.6$ & Invalid \\
\hline
\end{tabular}

Source: Azwar (2015)

For the practicality of the learning video, it is seen from the practicality sheet of the teacher and student participants. To find out the value obtained by dividing the scores obtained by students by the maximum score, 
and multiplying by 100 . Systematically the value of each indicator is determined from the equation:

$$
\text { Score }=\frac{\text { score obtained }}{\text { total score }} \times 100
$$

Based on the final value obtained, the practicality criteria for learning videos can be determined based on a modified interval scale from Azwar (2015), which is shown in Table 2.

Table 2. Product Practicality Categories

\begin{tabular}{ll}
\hline Interval & Category \\
\hline$\geq 61-100$ & Practical \\
$<61$ & Not practical
\end{tabular}

Source: Modification Azwar (2015)

The product practicality ranges that can be continued to the dissemination stage are products that are in the practical category with a range of $61-80$ and a very practical category with a range of $81-100$.

Whereas the analysis of the effectiveness of the use of instructional videos is obtained based on the results of measuring critical thinking skills. Analysis of the effectiveness of using the product was carried out using the t-test.

with

$$
\mathrm{t}=\frac{\overline{X_{d}}-\mu o}{S d / \sqrt{n}}
$$

and

$$
\overline{X_{d}}=\frac{\sum D}{n}
$$

$$
S_{d}=\sqrt{\frac{1}{n-1}\left\{\sum D^{2}-\frac{\left(\sum D\right)^{2}}{n}\right\}}
$$

Information:

$\mathrm{D}=$ Difference $\mathrm{X}_{1}$ and $\mathrm{X}_{2}$

$\mathrm{n} \quad$ number of data

$\mathrm{Sd}=$ standard deviation of $\mathrm{d}$

\section{Result and Discussion}

The ADDIE model is an instructional process that consists of five phases, namely analysis, design, development, implementation, and evaluation. The stages of the ADDIE Model are implemented as follows:

1. Analysis

a. Preliminary Study Analysis

Based on interviews that were conducted at 7 schools in West Sumatra regarding the media and teaching materials used by teachers at school, it was obtained data that the teacher said the media commonly used in schools when learning physics was PowerPoint media, but some teachers used video media. According to the teacher, learning media is very important to use in learning physics, but the use of media in school learning has not been implemented properly because of the many obstacles faced such as limited time for implementing the learning process and the limitations of media in school. So that the learning material described by the teacher to students is only fixated on the textbook. Only some teachers use media and teaching materials during the learning process. $46.1 \%$ of teachers use worksheets during the learning process, $9.2 \%$ of teachers use modules and $9.3 \%$ of teachers use encyclopedias, while other teaching materials such as dictionaries, reference books, and enrichment books are not used by the teacher at all during learning activities.

Based on previous surveys conducted by Navis, et al., 2019, the results showed that the implementation of scientific activities required by the 2013 curriculum had not been carried out optimally with an average value of $52 \%$ and the availability of learning media had not yet received adequate fulfillment facilities. The second problem that is obtained is the availability of media, resources, and teaching materials that are less than optimal to support the learning process. This can be seen from the percentage of media availability, sources, and teaching materials obtained. Where the percentage of learning using appropriate media, sources, and teaching materials is $35 \%$.

\section{b. Curriculum Analysis}

The curriculum analysis was carried out by reviewing the applicable curriculum at the school where the research was carried out, namely the 2013 curriculum. In this analysis, the curriculum used for Senior High School class XI was reviewed. The Competency Standards for Graduates (SKL) as outlined in Permendikbud No. 20/2016 describe Core Competencies (KI) and Basic Competencies (KD) that students must achieve during the learning process.

c. Material Analysis

The material analysis was carried out to determine the concepts of subject matter in accordance with the applied KI and KD. Teaching materials contain relevant facts, concepts, principles, and procedures written in the form of points in accordance with the formulation of competency achievement indicators. The material analysis aims to help teachers identify things that are fundamental to the knowledge and skills being taught and make it easier for students to master basic competencies.

d. Analysis of Teaching Materials

The analysis of teaching materials was carried out to see the availability of physics teaching materials for class XI Senior High School in seven schools. The teaching materials analyzed consist of textbooks, modules, worksheets, handouts, dictionaries, enrichment books, and reference books. The teacher is given a questionnaire to fill in the availability of learning media used at the school.

\section{Design}


The design stage includes several worksheets development plans including several activities, namely the preparation of worksheets in contextual-based learning by examining core competencies and basic competencies to determine learning material based on facts, concepts, principles and procedures, allocation of learning time. Designing scenarios for learning or teaching and learning activities. Develop instruments that will be used to assess the worksheets developed. The instrument is prepared by taking into account the aspects of the worksheets assessment, namely the aspects of content feasibility, presentation feasibility, language feasibility, and graphic feasibility. The instrument was arranged in the form of an instrument for the validity of the student worksheets assessment and the practicality assessment for the student and teacher worksheets. Furthermore, the instruments that have been prepared will be used to validate the worksheets.

\section{Development}

At this stage, the development of the worksheets is carried out according to the design. After that, the worksheets will be validated by experts, teachers, and students. In the validation process, the validator uses instruments that have been prepared in the previous stage. Validation is done to assess the validity of content, construct, and language. Validators are asked to provide an assessment of the worksheets developed based on the points of the worksheets feasibility aspects and provide suggestions and comments regarding the worksheets which will later be used to improve the worksheets improvement. Validation is carried out until finally the worksheets are declared feasible to be implemented in learning activities. At this stage, the researcher also analyzes data on the results of the worksheets assessment obtained from the validator. This is done to get the validity value of the worksheets. When the validator lecturer validates the contextual-based worksheets, some suggestions are submitted by the validator. In brief, the validator's suggestions are presented in Table 3.

Table 3. Summary of Validator Suggestions

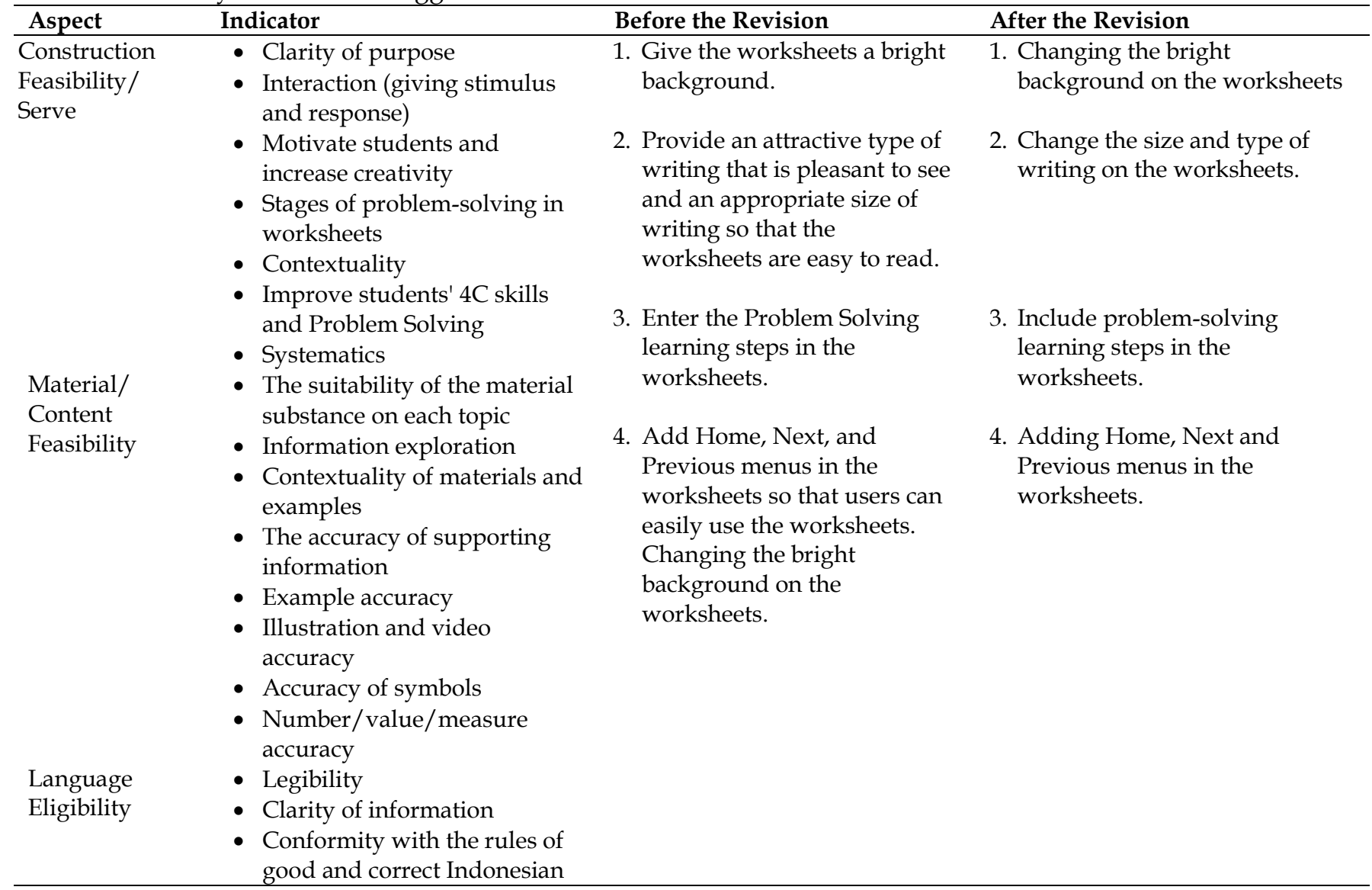

Based on the suggestions from the validator listed in Table 3, improvements have been made so that they produce valid contextual-based worksheets that can be used in learning activities. The results of the learning expert validator's assessment after improvements to contextual-based worksheets can be seen in Table 4 . 
Table 4. Results of Contextual-Based Student Worksheet Validation According to Learning Experts

\begin{tabular}{|c|c|c|c|c|}
\hline \multirow[t]{2}{*}{ No } & \multirow[t]{2}{*}{ Component } & \multicolumn{3}{|c|}{ Percentage of Validators } \\
\hline & & 1 & 2 & 3 \\
\hline 1 & The objectives presented in the worksheets are in accordance with Basic Competencies. & 0.75 & 1 & 0.75 \\
\hline 2 & Learning activities presented in the worksheets can foster student interaction. & 0.90 & 0.75 & 1 \\
\hline 3 & The material presented in the worksheets can foster student motivation. & 1 & 0.75 & 0.75 \\
\hline 4 & The learning activities presented in the worksheets can increase student creativity. & 0.75 & 0.75 & 0.50 \\
\hline 5 & The learning activities presented in the worksheets foster students' curiosity & 0.90 & 0.75 & 0.50 \\
\hline 6 & Learning activities in the worksheets provide experiences in defining problems. & 1 & 0.50 & 0.75 \\
\hline 7 & Learning activities in the worksheets provide experience in formulating problems. & 0.75 & 0.75 & 0.75 \\
\hline 8 & $\begin{array}{l}\text { Learning activities in the worksheets provide experience in collecting data and analyzing } \\
\text { data. }\end{array}$ & 0.75 & 0.75 & 0.50 \\
\hline 9 & $\begin{array}{l}\text { Learning activities in the worksheets provide experience in formulating conclusions and } \\
\text { solutions. }\end{array}$ & 1 & 0.75 & 0.75 \\
\hline 10 & The learning activities presented in the worksheets can verify conclusions and solutions. & 0.75 & 0.75 & 0.75 \\
\hline 11 & Learning activities refer to context videos found in insightful sessions. & 0.75 & 0.75 & 1 \\
\hline 12 & Learning activities refer to context videos contained in group study sessions. & 1 & 0.50 & 1 \\
\hline 13 & Learning activities refer to context videos contained in self-study sessions. & 1 & 0.75 & 1 \\
\hline 14 & $\begin{array}{l}\text { The learning activities presented in the worksheets can train students' critical thinking } \\
\text { skills. }\end{array}$ & 1 & 0.75 & 0.50 \\
\hline 15 & $\begin{array}{l}\text { The learning activities presented in the worksheets can train students' creative thinking } \\
\text { skills. }\end{array}$ & 0.85 & 0.75 & 0.50 \\
\hline 16 & The learning activities presented in the worksheets can train students' collaboration skills. & 1 & 0.50 & 0.75 \\
\hline 17 & $\begin{array}{l}\text { The learning activities presented in the worksheets can train students' communication } \\
\text { skills }\end{array}$ & 1 & 1 & 0.50 \\
\hline 18 & $\begin{array}{l}\text { The learning activities presented in the worksheets can practice problem-solving skills } \\
\text { scientifically. }\end{array}$ & 0.85 & 0.50 & 0.75 \\
\hline 19 & $\begin{array}{l}\text { Presentation of worksheets is arranged systematically, starting from the title, learning } \\
\text { instructions, competencies achieved, supporting information, learning activities, answers } \\
\text { to examples of cases, assessments, and bibliography. }\end{array}$ & 0.90 & 1 & 0.75 \\
\hline \multicolumn{2}{|c|}{ Average } & 0.84 & 0.74 & 0.72 \\
\hline \multicolumn{2}{|c|}{ Average of $\mathrm{V}$} & 0.77 & & \\
\hline
\end{tabular}

Based on Table 4, it can be seen that all indicators of student worksheet assessments are in the valid category with the average result of the validation of learning expert worksheets being 0.77. In other words, contextual-based worksheets can be used in learning activities with valid categories. The results of the contextual-based student worksheet validation according to physicists can be seen in Table 5 .

Table 5. Results of Contextual-Based worksheets Validation Analysis According to Physicists

\begin{tabular}{lll}
\hline No & Component & Percentage \\
\hline 1 & The substance of the material presented in the worksheets is in accordance with the topic. & 1 \\
2 & Examples of questions that are presented in the worksheets according to the topic. & 0.75 \\
3 & The learning activities presented in the worksheets can be used for exploration. & 0.75 \\
4 & The material substance presented in the worksheets is related to daily events. & 1 \\
5 & Examples of questions that are presented in the worksheets are related to everyday events. & 0.75 \\
6 & Supporting information presented in the worksheets according to the topic. & 1 \\
7 & Daily events are presented in material substance according to the topic. & 0.75 \\
8 & Daily events are presented in sample questions according to the topic. & 0.75 \\
9 & The illustrations are used according to the topic. & 1 \\
10 & Records of events discussed according to the topic. & 1 \\
11 & The symbols in the worksheets are presented according to the topic. & 1 \\
12 & The numbers/values/measurements in the worksheets are presented according to the topic. & 1 \\
Average & 0.90 \\
\hline
\end{tabular}

Based on Table 5, it can be seen that all indicators of student worksheet assessment are in the valid category with the average result of the validation of the physics expert's worksheet is 0.90 . In other words, 
contextual-based worksheets can be used in learning activities with valid categories. The results of the contextual-based student worksheet validation according to linguists can be seen in Table 6 .

Table 6. Results of Contextual-Based Student Worksheet Validation According to Linguists

\begin{tabular}{lll}
\hline No & Component & Percentage \\
\hline 1 & $\begin{array}{l}\text { The language used in the worksheets } \\
\text { is easy to understand. }\end{array}$ & 1 \\
2 & $\begin{array}{l}\text { The language used in the worksheets } \\
\text { is short and concise. }\end{array}$ & 0.75 \\
$3 \quad \begin{array}{l}\text { The language used is in accordance } \\
\text { with the correct Indonesian rules. }\end{array}$ & 0.75 \\
$4 \quad \begin{array}{l}\text { The language used is the standard } \\
\text { language. }\end{array}$ & 0.75 \\
Average & 0.81 \\
\hline
\end{tabular}

Based on Table 6, it can be seen that all the worksheets assessment indicators are in the valid category with the average result of the validation of the physics expert's worksheets is 0.81 . In other words, contextual-based worksheets can be used in learning activities with valid categories.

After the validity test of the worksheets was carried out, a practicality test was also carried out by teachers and students. This practicality test aims to see if this worksheet is practical to use in the learning process. The results of the teacher practicality test can be seen in Figure 1.

\section{Percentage of Teacher Practicality}

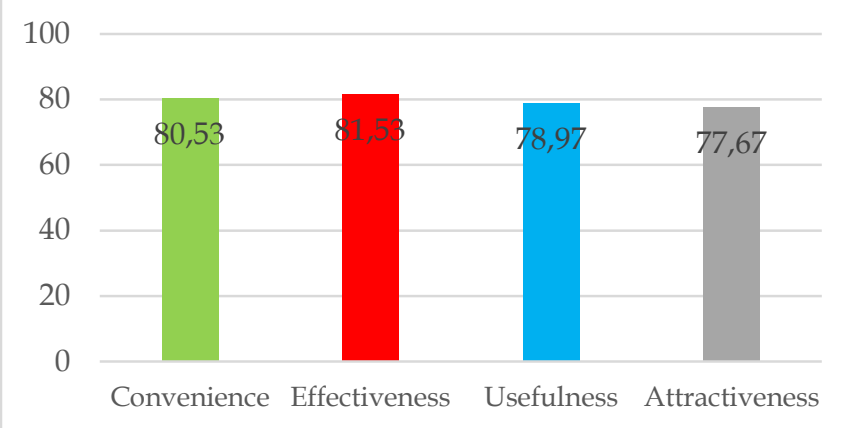

Figure 1. Results of Analysis of Practicality of Using Contextual-Based Worksheets According to the Teacher

Based on Figure 1, it can be seen that the average value of all indicators of practicality assessment of student worksheets by the teacher is 79.68 which is in the valid category. The results of the student practicality test can be seen in Figure 2 .

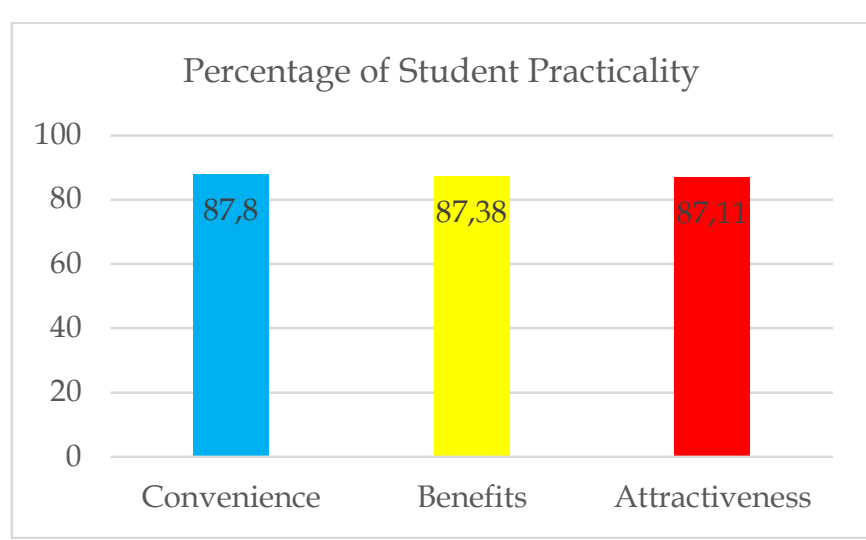

Figure 2. Results of Analysis of Practicality of Using Contextual-Based Worksheets According to Students

Based on Figure 2 it can be seen that the average value of all indicators of practicality assessment of student worksheets is 87.43 which is in the valid category.

\section{Implementation}

Implementation is limited to schools designated as research sites. At this stage, the researcher provides practical instruments to teachers and students that contain statement items about the use of student worksheets in learning. This is done to obtain data related to the practical value of using worksheets. In addition, teachers and students are also asked to comment on the worksheets assessed by teachers and students. after that, the teacher conducts the lesson with the help of the worksheets that have been developed. At the beginning of learning, students were given pretest questions to measure students' critical and creative skills in learning physics. After the learning process is complete, students are also given posttest questions to see the level of effectiveness of using the developed worksheets. The results of the analysis of the pretest and posttest assessments of critical and creative thinking skills can be seen in Tables 7 and 8 .

Table 7. Results of the Pretest and Postest Assessment of Critical Thinking Skills

\begin{tabular}{lll}
\hline No $\quad$ Component & $\begin{array}{l}\text { Percentage } \\
\text { of Pretest }\end{array}$ & $\begin{array}{l}\text { Percentage } \\
\text { of Posttest }\end{array}$ \\
\hline $\begin{array}{l}\text { Provide an explanation } \\
1 \quad \text { Identifying Questions }\end{array}$ & 51.7 & 58.3 \\
$2 \quad \begin{array}{l}\text { Suggest Answers } \\
\text { Conclude }\end{array}$ & 56.7 & 62.5 \\
$\begin{array}{l}3 \quad \text { Give a conclusion } \\
\text { Provide further explanation }\end{array}$ & 49.2 & 75.8 \\
$4 \quad \begin{array}{l}\text { Defines the terms } \\
\text { used in learning }\end{array}$ & 35 & 40 \\
Average & 48.1 & 59.2 \\
\hline
\end{tabular}

Based on Table 7, it can be seen that the average value of the pretest and posttest assessment indicators for critical thinking skills is 48.1 and 59.2 which are in 
the valid category. The results of the analysis of the pretest and posttest assessments of creative thinking skills can be seen in Table 8 .

Table 8. Results of the Pretest and Postest Assessment of Creative Thinking Skills.

\begin{tabular}{lll}
\hline No Component & $\begin{array}{l}\text { Percentage } \\
\text { of Pretest }\end{array}$ & $\begin{array}{l}\text { Percentage } \\
\text { of Posttest }\end{array}$ \\
\hline $\begin{array}{l}\text { Smoothness } \\
1 \quad \text { Have an answer to a } \\
\text { problem }\end{array}$ & 68.3 & 73.3 \\
$\begin{array}{l}\text { Originality } \\
2 \quad \begin{array}{l}\text { Provide unique/ } \\
\text { unusual/rare answers }\end{array}\end{array}$ & 51.7 & 75 \\
$\begin{array}{l}\text { Elaboration } \\
3 \quad \text { Generate broad ideas } \\
\text { Average }\end{array}$ & 45.8 & 53.3 \\
\hline
\end{tabular}

Based on Table 8 , it can be seen that the average value of the pretest and posttest assessment indicators for creative thinking skills is 55.3 and 67.2 which are in the valid category. The data on the increase in students 'pretest and posttest scores were used to determine students' critical and creative thinking skills. The average value of students' critical and creative thinking skills can be seen in Table 9 .

Table 9. Average Student's Critical and Creative Thinking Skills

\begin{tabular}{llllll}
\hline Assessment & \multicolumn{2}{l}{ Average } & & Category \\
\cline { 2 - 5 } & $\begin{array}{l}\text { Pre- } \\
\text { test }\end{array}$ & $\begin{array}{l}\text { Pos- } \\
\text { test }\end{array}$ & Gain & N-gain nn & \\
\hline Critical & 48.1 & 59.2 & 51.85 & 0.22 & Low \\
$\begin{array}{l}\text { Thinking } \\
\text { Skills }\end{array}$ & & & & & \\
\hline $\begin{array}{l}\text { Creative } \\
\text { Thinking }\end{array}$ & 55.3 & 67.2 & 44.73 & 0.26 & Low \\
Skills & & & & & \\
\hline
\end{tabular}

Based on Table 10, it can be seen that the N-gain value of the student's critical and creative thinking skills assessment is 0.22 and 0.26 are in the low category. This is because the research carried out online has many obstacles including first, the internet network does not support the research process which results in students being unable to effectively participate in learning activities. Second, the students' cellphones often have errors when playing contextual-based physics learning videos. Third, students do not usually learn online so that students have difficulty taking part in this online learning. Even though students have been given instructions on the use of instructional videos in online learning activities and have repeated them several times, students still have difficulty participating in online learning activities. So that online learning does not run effectively and affects the student's $\mathrm{N}$-gain score which becomes low. After testing the validity, practicality, and effectiveness, it can be concluded that the contextual- based physics learning video is suitable for use in learning activities at school.

\section{Evaluation}

At this stage, the researcher made the final revision of the worksheets developed based on the input obtained from the practicality assessment of teachers and students. It is intended that the worksheets developed is truly appropriate and can be used by a wider school.

\section{Conclusion}

Based on the analysis of the results of the worksheets validation assessment with learning expert lecturers, physicists, and language experts, it shows that contextual-based worksheets are valid for use in learning activities. It was obtained that the average assessment of the learning expert's worksheets was 0.77 , the average result of the physics expert's assessment was 0.90 and the average result of the linguist's assessment was 0.81 . In addition, the average results of the practicality assessment of student worksheets by teachers and students are 79.68 and 87.43 , in other words, student worksheets can be used in learning activities. Meanwhile, based on the results of the effectiveness test carried out at Senior High School 1 Gunung Tuleh to determine the effectiveness of learning activities using worksheets by training students 'critical and creative thinking skills at the time of learning activities, it was obtained that the average $\mathrm{N}$-gain value of students' critical and creative thinking skills was 0.22 and 0.26 .

\section{Acknowledgments}

Thank you to the Directorate of Research and Community Service, Directorate General of Strengthening Research and Development of the Ministry of Research, Technology and Higher Education for funding this research. Thank you also to the Institute for Research and Community Service of UNP, the Head of the Faculty of Mathematics and Natural Sciences, and the Chair of the Physics Education Master Program at Padang State University who have supported the implementation of this research.

\section{References}

Al-Adiyah, T., Ahied, M., Wulandari, A.Y.R., Hidayati, Y. (2018). Pengembangan Bahan Ajar Berbasis Komik "The Light Of Lift". Journal of Natural Science Education Reseach, 1(1).

Ardiva, A, \& Desnita. (2019). Preliminary studies to develop the instructional media in work and energy used ICT based-on contextual learning for 
senior high school. IOP Conf. Series: Journal of Physics: Conf. Series $1185 . \quad$ doi: http://10.1088/1742-6596/1185/1/012120

Asikin, M \& Cahyono, A.N. (2008), Penelitian Pengembangan Dalam Bidang Pendidikan. Makalah disajikan di Sekolah Riset FMIPA UNNES.

Asrizal, A., Amran, A., Ananda, A., \& Festiyed, F. (2018). Effectiveness of Adaptive Contextual Learning Model of Integrated Science by Integrating Digital Age Literacyon Grade VIII Students. IOP Conf. Series: Materials Science and Engineering 335 (2018) 012067 doi: http://10.1088/1757899X/335/1/012067.

Astra, I., Nasbey, H., \& Muharramah, N. (2015). Development of Student Worksheet by using Discovery Learning Approach for Senior High School Student. TARBIYA: Journal of Education in Muslim Society, 2(1), 91-96. doi:https://doi.org/10.15408/tjems.v2i1.1749.

Azwar, S. (2015). Reliabilitas dan Validitas. Yogyakarta : Pustaka Belajar.

Budiarso, A.S. (2016). Pengembangan Bahan Ajar Berbasis Metode Hypnoteaching Untuk Memotivasi Siswa SMP Dalam Belajar IPA Pada Materi Energi Terbarukan. Jurnal Pena Sains, 3(2). doi: https:// doi.org/10.21107/jps.v3i2.2349

Bustami, Y., \& Corebima, A,D. (2017). The Effect Of jiRQA Learning Strategy On Critical Thinking Skill Of Multiethnic Students In Higher Education, Indonesia. International Journal of Humanities Social Sciences And Education (IJHSSE), 4(3), 13-22. doi:dx.doi.org/10.20431/2349-0381.0403003

Cintamulya, I. (2015). Peranan Pendidikan dalam Memepersiapkan Sumber Daya Manusia di Era Informasi dan Pengetahuan. Formatif: Jurnal Ilmiah Pendidikan MIPA, 2(2). doi:http://dx.doi.org/10.30998/formatif.v2i2.89.

Depdiknas. (2006). Panduan Penyusunan Kurikulum Tingkat Satuan Pendidikan. Jakarta: BNSP Depdiknas.

Desnita, Raihanati, \& Leonda, M,A. (2014). PF-57: Strategi Workshop Penyusunan Bahan Ajar Fisika Berbasis Problem Based Learning Bagi Guru SMA/MA. Prosiding Seminar Nasional Fisika (EJournal) SNF 2014, Vol 3.

Fadhilah, F., Effendi, Z., \& Ridwan, R. (2017). Analysis of contextual teaching and learning (CTL) in the course of applied physics at the mining engineering department. International Journal of Science and Applied Science: Conference Series, 1(1), 25-32.

doi:http://dx.doi.org/10.20961/ijsascs.v1i1.510 $\underline{6}$.
Germaine, Ron, et all. (2016). Purposeful Use of 21st Century Skills in Higher Education. Journal of Research in Innovative Teaching, 9(1).

Hasanah, S., Purwoko, A., \& Hakim, A. (2020). The Effect of Guided Inquiry Learning Model on Chemistry Learning Outcomes. Journal of Science and Science Education, 1(1), 15-20. doi:https://doi.org/10.29303/jossed.v1i1.446.

Isnaningsih. (2013). Penerapan Lembar Kegiatan Siswa (LKS) Discovery Berorientasi Keterampilan Proses Sains untuk Meningkatkan Hasil Belajar IPA. Jurnal Pendidikan IPA Indonesia, 2(2). doi:https://doi.org/10.15294/jpii.v2i2.2714.

Jauhari, M. (2011). Implementasi PAIKEM dari Behavioristik sampai Konstruvistik: Sebuah Pengembangan Pembelajaran Berbasis CTL (Contextual Teaching and Learning). Jakarta: Prestasi Pustaka Publisher.

Kaymakci, S. (2012). A Review of Studies on Worksheets in Turkey. Online Submission, US-China Education Review A 1, 57-64.

Khairunnisa, I., Desnita, D, Putra, A., \& Hidayati H. (2020). Analisis Sajian Buku Teks Pelajaran Fisika SMA Kelas XII Semester 2 Terkait Komponen Pendekatan Contextual Teaching And Learning (CTL). Pillar of Physics Education, 13(1), 17-24. doi: http://dx.doi.org/10.24036/7964171074

Khasanah, B., Doyan, A., Gunawan, G., Susilawati, S., Kartini, K., Hakim, S., \& Muliyadi, L. (2019). Analysis Validation of Learning Media Quantum Phenomenon. Jurnal Penelitian Pendidikan IPA, $5(2)$, 189-193. doi:https://doi.org/10.29303/jppipa.v5i2.265

Kustijono, R., \& Wiwin HM, E. (2014). Pandangan Guru Terhadap Pelaksanaan Kurikulum 2013 Dalam Pembelajaran Fisika Smk di Kota Surabaya. Jurnal Penelitian Fisika dan Aplikasinya (JPFA), 4(1), 1-14. doi:http://dx.doi.org/10.26740/jpfa.v4n1.p1-14

Mahanal, S. (2014). Peran Guru Dalam Melahirkan Generasi Emas Dengan Keterampilan Abad 21. Makalah pada Seminar Nasional pendidikan. Online. https://www.researchgate.net/publication/319 746366. Diakses, 17 Oktober 2017

Navis, M, Y \& Desnita. (2019). Preliminary study to develop instructional media in momentum and impulses using ICT based on contextual learning for senior high school. IOP Conf. Series: Journal of Physics: Conf. Series $1185 . \quad$ Doi: http://10.1088/1742-6596/1185/1/012119.

Nieveen, N. (1999). Prototyping to Reach Product Quality. Jan Van den Akker, Robert Maribe Braneh, Ken Gustafson, and Tjeerd Plomp (Ed), London: Kluwer Academic Plubishers.

Nilawati, W., Desnita, D., \& Akbar, N. (2017). Perangkat Perkuliahan Terpadu Berbasis KPS untuk 
Meningkatkan Kompetensi Mahasiswa Pendidikan Fisika Mengembangkan Lembar Kerja Siswa. Jurnal Penelitian \& Pengembangan Pendidikan Fisika, 3(1), 103 - 110. https://doi.org/10.21009/1.03114.

Nursulistiyo, E., Puspitasari, A., Prabowo, Y., \& Kusumaningtyas, D. (2019). Student Learning Outcomes and Learning Evaluation in the Implementation of Physic Worksheet Based on Technological Excellence and Added with Islamic Values: Case Study for Male Students (Santri Putra). Advances in Social Science, Education and Humanities Research, $317 . \quad$ doi: https:// doi.org/10.2991/iconprocs-19.2019.17

Pineda, C. (2020). Effectiveness of Validated TeachingLearning Package in Projectile Motion for Grade 9 Science. Journal of Science and Science Education, 1(1), 26-29. doi:https://doi.org/10.29303/jossed.v1i1.454.

Puspita, I., Wahyuni, S., \& Yushardi, Y. (2017). Pengembangan Lks (Lembar Kerja Siswa) Fisika Berbasis Ctl (Contextual Teaching And Learning) Untuk Meningkatkan Collaborative Skills Siswa Di SMA. Jurnal Pembelajaran Fisika, 6(4), 376-382. doi:10.19184/jpf.v6i4.6230.

Putri, Y,A., Asrizal \& Yulkifli. (2018). Pengaruh Penggunaan LKS IPA Terpadu Bermuatan Keterampilan Literasi Tema Gerak Dalam Kehidupan Terhadap Kompetensi Siswa Kelas VIII SMPN 8 Padang. Pillar of Physics Education, 11 (1), 121-128. doi: http://dx.doi.org/10.24036/2710171074

Ramdani, A., Jufri, A., Gunawan, G., Hadisaputra, S., \& Zulkifli, L. (2019). Pengembangan Alat Evaluasi Pembelajaran IPA Yang Mendukung Keterampilan Abad 21. Jurnal Penelitian Pendidikan IPA, 5(1). doi:https://doi.org/10.29303/ippipa.v5i1.221.

Riduwan. (2009). Belajar Mudah Penelitian Untuk Guru, Karyawan dan Peneliti Pemula. Bandung: Alfabet.

Smith, Mc.K, Nieveen, N. \& van den Akker, (2010). Computer Support for Curriculum Developers: CASCADE. ETRED, 50(4): 25-35.

Sugiyono. (2017). Metode Penelitian Kuantitatif, Kualitatif dan RED. Bandung: Alfabeta.

Susialita, T. (2016). The Development Of Audio-Visual Student Portfolios (LKS) Contextual Teaching And Learning-Based (CTL) On Sound Chapter Of Science Subject for Deaf Students. Jurnal Pendidikan IPA Indonesia, 5(2), 192-198. doi:https://doi.org/10.15294/jpii.v5i2.6734.

Tegeh, M. (2014). Model Penelitian Pengembangan. Yogyakarta : Graha Ilmu.

Undang-Undang Republik Indonesia Nomor 20 Tahun 2003 tentang Sistem Pendidikan Nasional.
Zikrullah, M., Wildan, W., \& Andayani, Y. (2017). Pengembangan Lembar Kegiatan Siswa (LKS) Model Learning Cycle 5E. Jurnal Penelitian Pendidikan IPA, 2(2). doi:https://doi.org/10.29303/ippipa.v2i2.40. 